\title{
BANK REGULATION IN THE UNITED STATES:
}

UNDERSTANDING THE LESSONS OF THE 1980s AND 1990s

Lawrence J. White

Stern School of Business

New York University

Presented at the panel

discussion of

"Reform of Banking Regulation

in Japan and the U.S.",

Center for Japan-U.S. Business

and Economic Studies,

Stern School of Business

New York University

October 26, 1999

Draft, 10/20/99

Do not cite or quote

without permission of the author

Comments welcomed

\begin{abstract}
:
Despite two decades of extensive deregulation, banks in the United States remain among the most heavily regulated entities in the U.S. economy. Partly, banks remain a prominent target for American populism and its political manifestations; but also important is the general recognition that one specific category of bank regulation -- safety-and-soundness (prudential) regulation -- is a crucial element in preserving the stability of the banking system and contributing to the health of the U.S. economy. This paper expands on that theme and discusses the important lessons and insights that can be gained from the experiences of the banking sector and of safety-and-soundness regulation during the past two decades.
\end{abstract}




\title{
BANK REGULATION IN THE UNITED STATES: \\ UNDERSTANDING THE LESSONS OF THE 1980s AND 1990s
}

\author{
Lawrence J. White \\ Stern School of Business \\ New York University
}

\section{Introduction}

Despite two decades of extensive deregulation, banks in the United States remain among the most heavily regulated entities in the U.S. economy. This continued heavy regulation is surely due to a mixture of causes: Partly, banks remain a prominent target for American populism and its political manifestations; ${ }^{1}$ but also important is the general recognition that one specific category of bank regulation -- safety-and-soundness (prudential) regulation -- is a crucial element in preserving the stability of the banking system and contributing to the health of the U.S. economy.

This paper will expand on this theme and discuss the important lessons and insights that can be gained from the experiences of the banking sector and of safety-and-soundness regulation during the past two decades. An important "instructor" for this learning has been the episodes of extensive lapses of safety-and-soundness regulation during these decades, leading to the insolvencies of large numbers of savings and loan (S\&L) associations and banks in the 1980s and early 1990s.

The remainder of the paper will proceed as follows: Section II will survey briefly the various types of bank regulation that can be found in the U.S., so as to clarify our focus on safetyand-soundness regulation. Section III will then discuss the phenomenon of asymmetric information, which lies at the heart of financial transactions, and its implications for the activities

\footnotetext{
${ }^{1}$ For further discussion of this phenomenon, see White (1993) and Shull and White (1998).
} 
and role of banks. Section IV will apply the asymmetric information paradigm to banks themselves and thereby illuminate the role of safety-and-soundness regulation and the primary tools that are employed. Section V will discuss the lessons that have been learned from the experiences of the 1980s and 1990s. And Section VI will provide a brief conclusion.

To establish a framework or "vocabulary" for the discussion of banks and bank regulation that follows, Figure 1 offers a stylized version of a bank's balance sheet. Its assets are the loans that it makes, since it expects to be paid back, with interest. Its liabilities are the deposits that it has accepted (which provide the funding for the loans), since it owes that amount (is liable) to the depositors. The arithmetic difference between the value of the loan assets and the value of the deposit liabilities is the net worth of the bank -- its owners' equity -- or, as the phrase is commonly used in banks, its capital. So long as the value of the bank's assets exceeds the value of its liabilities -- i.e., so long as its capital is positive -- the bank is solvent. 


\section{Understanding Bank Regulation}

At first glance, the web of regulation that surrounds banks ${ }^{2}$ in the U.S. (and in virtually all other countries as well) seems to be an impenetrable mass of restrictions and requirements. And, in the U.S. especially, efforts to understand bank regulation are not aided by the separate but overlapping jurisdictions of the federal government and the 50 states; by the presence of three federal regulators (the Federal Reserve System, the Federal Deposit Insurance Corporation [FDIC], and the Office of the Comptroller of the Currency [OCC] that have separate but overlapping jurisdictions with respect to commercial banks; and by the existence of other categories of depository institutions (S\&Ls, savings banks, and credit unions) that have many of the functions of banks (and are tending to take on more of them), that are sometimes described as "banks", and that have their own separate panoply of regulatory institutions and laws and regulations. The printed laws and regulations that apply to commercial banks would occupy many linear feet on a legal library book shelf; the addition of the laws and regulations that apply to the other depository institutions would extend the length appreciably.

Nevertheless, there is a way of making sense out of this apparent jumble. ${ }^{3}$ To do so, we will employ a general three-way classification scheme for regulatory interventions.

\section{A. A typology of regulation.}

\footnotetext{
${ }^{2}$ Unless otherwise indicated, we will use the phrase "banks" to refer to depository institutions generally. In some instances, however, we will be referring specifically to "commercial banks", which are the banks that are regulated by the three federal agencies mentioned in the text below and which have an historical legacy of emphasizing commercial lending.

${ }^{3}$ See White (1994).
} 
1. "Economic regulation". This category of regulation broadly involves governmental controls with respect to prices, profits, and/or conditions of entry and exit, including must-serve obligations. ${ }^{4}$ With respect to banking, such regulation would apply to any limits on interest rates that can be charged on loans or paid on deposits; limits on fees for other financial services; limits on de novo entry and on the establishment of new branch locations by incumbents; limits on the fields and activities into which banks can enter; and requirements that banks provide services to specific industry sectors and/or specific geographic areas.

It is important to note that this is the category of regulation that has been most affected by the wave of deregulation that has occurred in a number of sectors in the U.S. economy, including banking, over the past 20 years. Indeed, a "snapshot" of the banking sector 20 years ago would have revealed a much more extensive pattern of federal and state regulation -- controls on deposit rates, de novo entry restrictions, branching restrictions, etc. -- than exist today. Nevertheless, some important features of economic regulation remain: e.g., the federal ban on the payment of interest on commercial checking account deposits, some states' restrictions on credit card fees, a few states' restrictions on branching, the federal restrictions on the entry of banks into areas outside of traditional commercial banking (including the areas of investment banking, insurance, and nonfinancial areas generally); ${ }^{5}$ the federal requirement that banks "meet the needs" of their local communities, etc.

2. "Information regulation". This form of regulation involves the requirements that specific

\footnotetext{
${ }^{4}$ Outside of banking, such regulation was typified by the blanket control over airline fares, routes, and entry and exit that the former Civil Aeronautics Board exercised prior to the late 1970s. It is still found in the area of local electricity, telephone, water, and gas rates, local taxicab regulation in many ares, etc.

${ }^{5}$ This limitation is reciprocal, so enterprises in these other areas cannot own and operate banks.
} 
types of information, often in a standardized format, that must be provided with the product or service. ${ }^{6}$ In banking, the requirements that banks provide standardized information on deposit rates and loan rates to their customers are major examples of this form of regulation.

3. "Health-safety-environment (HSE) regulation". ${ }^{7}$ This category of regulation broadly encompasses restrictions on the types of products that a firm can offer and the types of production processes in which it can engage. ${ }^{8}$ For banks, "safety-and-soundness" regulation is aimed primarily at preventing the insolvency of banks. The instruments of safety-and-soundness regulation are primarily minimum capital (net worth) requirements (so as to provide a financial buffer against potential insolvency), limitations on banks' activities (so as to limit the riskiness of the activities of banks), and the monitoring of the honesty and competency of banks' managements and operations (so as to avoid the insolvencies that might follow from dishonest or incompetent management). Safety-and-soundness regulation is sometimes described as a process of "examination and supervision," since it is enforced through a field force of "examiners" and "supervisors".

As was mentioned in the introductory Section, safety-and-soundness regulation will be the primary form of regulation that is discussed in this paper.

\section{B. Uses of the typology.}

This three-way typology of regulation does not eliminate all ambiguities. Activities

\footnotetext{
${ }^{6}$ Outside of banking, the labels that accompany pharmaceuticals, the labels on packaged foods, and the disclosure-of-information requirements for publicly traded companies are typical examples.

${ }^{7}$ This is sometimes described as "social regulation."

${ }^{8}$ Outside of banking, this form of regulation is manifested in aviation safety requirements, environmental regulations, workplace safety requirements, pharmaceutical safety requirements, etc.
} 
limitations on banks might be considered to be a barrier to entry (economic regulation) or a riskrestraining effort (safety-and-soundness regulation). The preparation of bank balance sheets according to a standardized accounting framework ("generally accepted accounting principles", or GAAP) aids examiners and supervisors and helps define capital (safety-and-soundness regulation), but it is also useful for any investor or depositor who is interested in the financial condition of his/her bank (information regulation).

Despite these ambiguities, however, this classification scheme is broadly useful for linking the types of regulatory actions with the likely motives for regulation. In principle, economic regulation could be used for restraining the exercise of market power, information regulation could be used for dealing with problems of informational deficiencies, and H-S-E regulation could be used for dealing with problems of negative externalities (spillover effects) as well as severe problems of informational deficiencies (where the required provision of the information alone might not be sufficient to deal with the problem). In practice, of course, political forces come into play, and parties that are affected by regulation often try to influence outcomes in their favor, so that (for example) much economic regulation has come to represent efforts to protect incumbents and thus exacerbate problems of market power rather than alleviating them. ${ }^{9}$ Nevertheless, the ability to link types and motives of regulation helps clarify the role of regulation.

${ }^{9}$ Indeed, it was the political recognition that, in many instances, this type of regulation was impeding competition that contributed to the wave of deregulation of the 1970s and 1980s. 


\section{The Asymmetric Information Paradigm and Its Implications}

for the Patterns of Finance

In order to understand the role and importance of safety-and-soundness regulation for banks, a brief discussion of the basic processes and problems of finance generally and of banks specifically is worthwhile.

\section{A. The Inherent Asymmetric Information Problem of Finance.}

Financial transactions are different from most other economic transactions, in that financial transactions have an unavoidable time sequencing structure: They involve an initial transfer from a lender to borrower (or from an investor to the recipient of invested funds ${ }^{10}$ ) and then a later repayment.

Because of this time sequencing, the lender has to be concerned about being repaid. But information asymmetries between the borrower and the lender will adversely affect the lender's ability to determine the prospects of repayment. First, before the lender grants the loan, the borrower is likely to know more about its own risk characteristics and prospects for repayment than does the lender, which can create the problems of adverse selection: If there are no sanctions (or weak sanctions) for non-repayment, risky borrowers are likely to be more eager to borrow (and to be more willing to pay higher interest rates to borrow) than are less risky borrowers. ${ }^{11}$ Second, after

\footnotetext{
${ }^{10}$ For terminological ease we will continue to describe such transactions as "loans", but the basic concepts apply with equal force to equity investment arrangements. They also apply to insurance arrangements, where the insurer's initial promise to provide insurance coverage to an insured then creates the same types of problems. And these problems arise, for the same inherent reasons, in rental and lease markets.

${ }^{11}$ See Stiglitz and Weiss (1981).
} 
the borrower has received the funds, moral hazard problems arise: In the absence of sanctions for non-repayment, the borrower's behavior will become more risk-prone, since the borrower will receive all of the "upside" benefits from undertaking greater risks but will not bear the "downside" costs.

Lenders' recognition of these potential problems in turn causes the lenders to become information gatherers: ${ }^{12}$ Before the granting of a loan, lenders will want to gather information about the prospective borrowers' likelihoods of repayment; and during the term of the loan the borrower will continue to monitor the borrower's behavior and financial condition, so as to be reassured that the borrower's likelihood of repayment has not diminished.

\section{B. Implications for the Structure of Finance.}

Differing characteristics among prospective borrowers and differing information-gathering skills among prospective lenders have logical consequences for the structure of finance. These implications are portrayed in Figures 2 and 3.

In Figure 2 we array potential borrowers along a spectrum of their informational opaqueness or transparency. ${ }^{13}$ At the left-hand side of Figure 2, the most opaque potential borrowers will have the most difficulties in arranging for finance and will (at best) have to rely on "friends and family" and other informal sources for their finance. Such informal sources are likely to have special information about the borrowers' abilities to repay and/or to have special means of extracting

\footnotetext{
12 Even if there are no inherent informational asymmetries between borrowers and lenders but there are differences among prospective borrowers with respect to their abilities/proclivities to repay, the lenders will have the same incentives to gather information about the borrowers.

${ }^{13}$ See Berger and Udell (1993).
} 
repayment (or to be more willing to forgo repayment). At the right-hand side of Figure 2, the most transparent borrowers will have the most ease in obtaining loans and will be able to access the securities markets, where the lenders (bond buyers/investors) are the least able to scrutinize borrowers beforehand or to monitor borrowers during the term of the loan.

Borrowers of intermediate opaqueness/transparency are likely to rely on lenders that are information specialists -- lenders with special information gathering expertise and monitoring capabilities -- for their finance. These specialists include financial intermediaries (such as banks and other depository institutions, commercial and consumer finance companies, insurance companies, and mutual funds or investment trusts), supplier firms (providing short-term trade credit), and the special finance subsidiaries of equipment suppliers (providing, in essence, longerterm trade credit). Further, the structure of the lending/borrowing arrangement will be sensitive to the opaqueness of the borrower: More opaque borrowers are likely to receive shorter (and/or more callable) loans on which they pay higher interest rates and for which they are more likely to be asked to post collateral. ${ }^{14}$

The boundaries that separate the types of borrowers (and where they get their finance) are not rigid and will be affected by prevailing legal arrangements, by the transparency of accounting conventions, and by the current state of data gathering and processing technologies. To the extent that lenders have greater legal reassurance that they will be repaid (e.g., greater ability to seize collateral and repossess assets and greater certainty about priorities in bankruptcy arrangements), they will be more willing to lend to borrowers that would be otherwise too opaque. ${ }^{15}$ Further,

\footnotetext{
${ }^{14}$ See Strahan (1999).

${ }^{15}$ See Laporta et al. (1997, 1998) and Levine (1998, 1999).
} 
greater transparency in accounting (on the part of enterprises) will make the lender's task of determining the riskiness of the borrower easier, while opaque accounting will make these determinations more difficult and will likely cause the lender to "fear the worst", thereby discouraging lending; uniformity of accounting treatment across enterprises will make comparisons easier.

Improvements in the technologies of data collection and assessment make the lenders' information gathering and monitoring tasks easier and tend to push to the left the boundaries portrayed in Figure 2. Thus, as the technologies of telecommunications and data processing have improved dramatically in the past few decades in the U.S., more types of borrowings have tended to be "securitized" and thus the securities markets have encompassed more borrowers (e.g., junk bonds, mortgage-backed securities, other types of asset-backed securities), while banks and other intermediaries have been able to penetrate more deeply into the area of opaque borrowers, making credit card loans to households and small enterprises and even making more small business loans that were previously considered too risky.

Accordingly, in Figure 2 we portray the boundaries between the various types of borrowers and their prospective lenders with a wavy line, which is meant to convey the concept of fuzzy boundaries that vary according to the legal, accounting, and technological conditions that are present.

In Figure 3 we provide two important characteristics of informational opaqueness/transparency for enterprise borrowers -- their size and their age -- and show how borrowers with these characteristics will tend to be matched with the various types of lenders. Young firms tend to be opaque; they have a limited "track record" from which lenders can make 
judgments. Small firms require small amounts of financing, which would not justify the fixed-cost expenses of information gathering and assessment that a specialized lender would require. Accordingly, very young, small enterprises are likely to have to rely on "friends and family" and informal finance. As firms grow older and larger, they may be able to obtain trade credit and to attract the attention of banks or other financial intermediaries. Finally, when they are sufficiently large and mature, they can directly access the securities markets. Again, in Figure 3 we have drawn the boundaries as wavy (fuzzy) lines, since these boundaries will depend on legal, accounting, and technological arrangements.

This asymmetric-information based approach to the structure of finance thus indicates that there is an important role for banks and bank-like entities, which act as information specialist lenders vis-a-vis borrowers that are in the intermediate range of informational opacity/transparency. ${ }^{16}$ Small and medium-size enterprises with modest "track records" are clearly in this intermediate category. Banks have historically held this role of lender to borrowers in the intermediate category, since banks' relative sizes have given them advantages of expertise, scale, and diversification in dealing with borrowers, which individual lenders would be unlikely to have. In addition, since borrowers (especially enterprise borrowers) are likely also to maintain their checking accounts with the lending bank, that bank may be able to use this information so as to be able to monitor its borrowers more effectively. ${ }^{17}$

\footnotetext{
${ }^{16}$ See also Gorton and Winton (1998).

${ }^{17}$ See Nakamura (1993).
} 


\section{Asymmetric Information and The Role of Safety-and-Soundness Regulation}

As Section III indicated, banks and bank-like intermediaries are likely to play an important role in providing finance in an economy, especially for small and medium-size enterprises. ${ }^{18}$ Historically this has indeed been true in the U.S.; and, despite a substantial decline over time in the relative role of banks within the financial sector, ${ }^{19}$ banks remain a sizable and important source of finance in the U.S. economy. Table 1 provides a few of the salient characteristics of U.S. commercial banks, as of June 30, 1999.

Relative importance alone, however, would not justify a role for safety-and-soundness regulation. Instead, we must look to the special nature of banks.

\section{A. The potential for moral hazard behavior.}

The financial structure of a typical bank makes it prone to the same type of moral hazard behavior problems that were described in Section III when we discussed the problems of lenders in general. To illustrate this point, in Figure 4A we reproduce the bank balance sheet of Figure 1. In the discussion that follows it is crucial to remember that the bank's depositors, as its liability holders, are in the position of lenders to the bank.

If the bank experiences losses and the value of its assets declines to, say, $\$ 80$ (because some borrowers cannot repay their loans), the bank has become insolvent, as is portrayed in Figure 4B. The bank's owners' stake has been eliminated, and, under a legal system of limited liability for

\footnotetext{
${ }^{18}$ For international evidence that banks are important for economic growth and development, see Levine (1998) and Levine and Zervos (1998).

${ }^{19}$ See Litan (1987), Edwards (1996), and Kroszner (1996).
} 
owners, they cannot be held liable for any losses beyond the elimination of their equity. Thus, the only other absorbers of the insufficient value of the assets must be the depositors. In the absence of any other arrangement, the bank of Figure 4B would have to close, its assets would be liquidated (for their $\$ 80$ value), and the depositors would somehow allocate the $\$ 80$ among themselves to satisfy their $\$ 92$ in claims. ${ }^{20}$

The limited liability arrangement thus creates moral hazard behavior incentives for bank owners (or bank managers on the owners' behalf) to engage in excessively risky lending. ${ }^{21}$ The bank owners will capture the benefits from the "upside" outcomes of risky ventures; but their losses from the "downside" outcomes are limited to their equity stake. Such excessively risky lending will have negative expected values and thus imply inefficient investments.

If depositors were information specialists who could readily assess the riskiness of their bank's activities, they could monitor their bank's activities and protect themselves (in the same way that the bank protects itself in its role as lender). But, for the most part, depositors are not information specialists and are unlikely to be able to protect themselves adequately as lenders to banks. Thus, the potential for moral hazard behavior by banks is ever-present.

B. The role of safety-and-soundness regulation.

In the light of the previous discussion, the safety-and-soundness regulation of banks ought to be seen as the public sector equivalent (on behalf of depositors) of the restrictions that banks,

${ }^{20}$ If, instead, an acquiror were considering taking over the insolvent bank, it would insist that the depositors relinquish $\$ 12$ of their claims, so as to bring the liabilities into equality with the (diminished) level of assets.

${ }^{21}$ This problem of moral hazard arising from limited liability is, of course, a general one and applies to all corporations vis-a-vis their creditors; it underlay much of the discussion on Section III. 
bond holders, and other lenders impose (in the form of lending agreements and covenants) on a borrowing enterprise, so as to reassure themselves of repayment. ${ }^{22}$ As was noted in Section II, the primary tools of safety-and-soundness regulation are activities restrictions, so as to prevent the bank from engaging in excessively risky activities (the "downside" of which could cause insolvencies); general monitoring of the honesty and competency of the bank's management and operations, so as to avoid insolvencies due to incompetence; and minimum capital requirements, so as to maintain a financial buffer against insolvency.

This terse overview does not do nearly enough justice to the myriad complexities of the day-to-day processes of safety-and-soundness regulation. Nevertheless, the basic logic and rationale for these efforts can be seen in terms of the bank balance sheets of Figures 4A and 4B. The downside losses from excessively risky activities could reduce the value of the bank's assets sufficiently so as to cause insolvency. Dishonest or incompetent management could similarly diminish the value of the assets, deliberately (e.g., by "taking the money and running") or inadvertently, so as to cause insolvency. The insistence on the maintenance of a minimum level of capital, with tighter restrictions and closer monitoring if the bank's capital falls below the minimum level, provides a financial buffer against accidental or unexpected declines in asset values and consequent insolvency. Further, a required minimum level of capital provides an important indirect benefit: The larger is the owners' equity stake in the bank, the greater is the loss that they will incur from the downside of risk-taking (before their limited liability protections become applicable) and thus the less inclined they will be to take risks in the first place.

${ }^{22}$ A similar logic would apply to the safety regulatory protections that are provided to the insured parties of insurance companies and the pension claimants of defined benefit pension plans; and it is no accident that the claimants of these financial entities are provided with governmental guarantees that are similar in nature to the deposit insurance that applies to banks. 
These efforts do not always work perfectly. Indeed, the wave of S\&L and bank insolvencies in the U.S. in the 1980s and early 1990s were a clear indication of the imperfections of past safetyand-soundness regulation, as will be discussed in Section V. But monitoring by private-sector lenders of their borrowers' activities is not always perfect either; borrower bankruptcies do occur. The logic of these monitoring efforts, however, is clear for both the private and public sectors.

Since 1933 the federal government has supplemented safety-and-soundness regulation with explicit deposit insurance, as an extra protection for depositors (against a failure of safetysoundness-regulation to protect them adequately). ${ }^{23}$ With the presence of deposit insurance (and with the deposit insurance agency bearing the losses of bank insolvencies), safety-and-soundness regulation can also be interpreted as the public-sector equivalent of the rules and procedures that insurance companies use to protect themselves against losses. The logic of the tools remains the same.

C. The unstable structure of banks.

The problems of bank insolvency discussed above are exacerbated by the maturity and liquidity mis-match of the typical bank's assets and liabilities. The bank's loan assets tend to be of longer maturity and less liquid than its deposit liabilities, most of which can be withdrawn at relatively short notice. No bank can meet the simultaneous demand of all of its depositors for their funds.

${ }^{23}$ Federal deposit insurance, through the establishment of the FDIC, was first authorized for commercial banks and savings banks in 1933; in 1934 it was extended to depositors in S\&Ls, through the establishment of the Federal Savings and Loan Insurance Corporation (FSLIC) (which was dissolved in 1989, with the FDIC as its successor); and in 1970 it was extended to depositors in credit unions, through the establishment of the National Credit Union Administration (NCUA). 
This mis-match thus creates the potential for depositor runs, which can force the closure of even solvent banks. ${ }^{24}$ If depositors fear -- correctly or incorrectly -- that their bank's assets have declined substantially in value, they will rush to the bank to withdraw their funds, so as to avoid bearing some of the losses of the feared insolvency. Even if their fears are baseless, the withdrawals by enough poorly informed depositors could cause the bank to be unable to honor its liquidity commitments to those depositors. As a consequence, even well-informed depositors who know that the bank's assets have not lost value will also rush to withdraw their deposits, in fear that the former group's withdrawals may impede the latter's access to their funds. Their rush to the bank will exacerbate the bank's liquidity problems. And if its inability to meet its depositors' withdrawal requests causes the bank to close and liquidate its assets -- i.e., call in its loans -- then even an originally solvent bank may become insolvent as its loans cannot be repaid in full on short notice.

Further, if poorly informed depositors in neighboring banks fear that similar problems could affect their banks, and depositor runs could be contagious. Alternatively, a run on one bank might impair the claims of other banks, creating a cascade of failed banks.

In principle, a lender of last resort -- the Federal Reserve, as central banker -- could provide sufficient short-term liquidity lending to solvent banks to allow them to withstand runs. But the lender of last resort would require information as to which banks were truly solvent and would have all of the concerns of a lender with respect to its loans to the banks, which means the virtual recreation of a safety-and-soundness regulatory system.

In sum, because of the structural characteristics of banks and because depositors are likely to be poorly informed as to the solvency of their banks, safety-and-soundness regulation continues

\footnotetext{
${ }^{24}$ See Diamond and Dybvig (1983) and Postlewaite and Vives (1987).
} 
to be an essential feature of the U.S. banking system. 


\section{$\underline{\text { V. The Experience of the 1980s and the Early 1990s, and the Lessons }}$}

After the financial trauma of the 1929-1933 period, when many thousands of banks and other depository institutions failed, ${ }^{25}$ the federal government imposed substantially tighter regulatory controls on banks and other depository institutions. Partly these involved "economic regulation" measures, such as controls on entry, restrictions on interest rates paid on deposits, and restrictions on entry into other fields (such as investment banking); and partly they involved tighter safety-and-soundness regulatory measures. Also, federal deposit insurance was offered for the first time. And new governmental agencies were created.

The combination of these measures, plus the stabilization of the U.S. economy by the mid 1930s, ended the trauma for banks and their depositors. The subsequent growth of the U.S. economy during the Second World War and the three decades following the war meant stable and prosperous banking markets. Table 2 provides the decade totals of bank failures. As compared with what would follow in the 1980s and early 1990s, the earlier decades were clearly a period of calmness. A similar picture would describe the S\&L industry.

The 1980s, however, did bring a different experience. The S\&L experience, which we will describe first, attracted the greatest public attention --for good reason. But the bank experience, which we will next describe, was also important, since it reinforced many of the lessons of the S\&L debacle. This Section will conclude with those lessons.

${ }^{25}$ Over 9,750 commercial banks failed during 1929-1933, with 4,000 failing in 1933 alone; there were thousands more failures of S\&Ls and savings banks. 
The S\&L experience. ${ }^{26}$

Despite four decades of growth and prosperity, the S\&L industry entered the 1980s in a weak position. The industry had been constrained to be a lender for residential real estate mortgages, and to make fixed-rate, long-term mortgage loans. Simultaneously, S\&Ls funded themselves by taking in mostly short-term deposits. This position -- "borrowing short and lending long" - meant that they were vulnerable to general increases in the levels of interest rates. When a sustained period of higher interest rates began in 1979, S\&Ls began to hemorrhage.

The Congress responded in 1980 and again in 1982 with legislation that reversed the pattern of economic regulation that had previously constrained the industry. Many states followed, and sometimes led, with deregulation measures of their own. S\&Ls were permitted to expand their asset portfolios to include other kinds of loans and were permitted to make adjustable rate mortgages. Interest rate ceilings on deposits were removed, and the maximum insured amount was increased to $\$ 100,000$ (from $\$ 40,000$, where it had been since 1974).

Though the deregulation measures were at least a decade too late in coming, they still represented a worthwhile loosening of restraints. But these measures needed to be accompanied by strengthened safety-and-soundness regulation, because many S\&Ls were in strained financial positions -- with low capital levels -- which meant that they had great incentives for risk-taking.

Unfortunately, the opposite occurred. Minimum capital levels were decreased; the accounting framework that applied to S\&Ls for regulatory purposes was modified, so as to allow S\&Ls artificially to report higher levels of capital; and the numbers of supervisors and examiners was decreased. Compounding this problem was a lulled sense of danger on the part of the

\footnotetext{
${ }^{26}$ See White (1991) and FDIC (1997, ch. 4).
} 
personnel of the regulatory agency for S\&Ls, the Federal Home Loan Bank Board (FHLBB). Since the S\&L industry had caused few problems in the previous 45 years, this lulling was understandable. Nevertheless, it was unfortunate.

In this less constrained environment hundreds of S\&Ls grew rapidly between 1983 and 1985, often making risky or ill-conceived loans in the newly opened categories. The aggregate amount was well over $\$ 100$ billion. This rapid growth would likely have yielded problems in any event. But the problems were compounded by three exogenous events: First the price of petroleum had risen sharply in 1973-74 and again in 1979; many individuals predicted that petroleum prices would rise yet further. Many of the new loans were in commercial real estate in the southwestern part of the U.S. and were dependent on a high or rising price of petroleum. But, after hitting a peak in early 1981, petroleum prices drifted downward for the next five years and then fell sharply in early 1986. They recovered subsequently but have never regained their 1981 nominal levels. With the decline in petroleum prices went the fate of many of the new commercial real estate loans by S\&Ls and ultimately the fate of the S\&Ls.

Second, the federal Economic Recovery Tax Act of 1981 had greatly enhanced the tax advantages that attached to investing in commercial real estate. Many S\&Ls' loans were predicated on the tax-advantaged economics of the underlying projects. But the Tax Reform Act of 1986 reversed course and removed the favorable position of real estate. With this reversal went again a reversal of fortune of many S\&Ls' real estate loans and then the S\&Ls themselves.

Third, an idiosyncratic but unfortunate occurrence was the timing of the transfer of a regulatory field office of the FHLBB from Little Rock to Dallas. This office had responsibility for S\&Ls in Texas, Louisiana, Arkansas, Mississippi, and New Mexico. The transfer took place in mid 
1983, and the office was substantially disrupted for over two years -- at just the time that rapid growth in the Southwest was occurring.

In late 1984 the FHLBB began to reverse course and to tighten safety-and-soundness regulatory standards and also greatly expanded its filed force of examiners and supervisors. By the end of 1986 the regulatory system was considerably tighter than it had been three years earlier. But the damage had been done. The risky loans had already been made and were going sour. The recognition of the poor quality of the loans and the consequent insolvencies of hundreds of S\&Ls would take time -- partly because accounting practices are backward looking and are slow to recognize changes in current values of assets, and partly because real estate markets in the Southwest and elsewhere continued to crumble in the late 1980s.

The FHLBB struggled to deal with the debacle of hundreds of insolvent S\&Ls but was hampered by inadequate funds and inadequate political recognition of the depth of the problem. In 1989 the Bush Administration and the Congress took the first steps to deal with the problem. The S\&L's deposit insurance fund, the FSLIC, was finally recognized to be insolvent itself; substantial taxpayer funds would be required to cover the deposit insurance guarantees in the hundreds of failed S\&Ls. Legislation provided a first tranche of funds for a cleanup, abolished the FHLBB and the FSLIC, established new agencies for regulating S\&Ls (the Office of Thrift Supervision [OTS]) and for cleaning up the "debris" of hundreds of insolvent S\&Ls (the Resolution Trust Corporation [RTC]), and transferred the deposit insurance coverage for S\&Ls to the FDIC. Legislation in subsequent years finished the job.

In the end, over 1,200 S\&Ls failed between 1980 and 1994. Though the major damage was done between 1983 and 1985, the delayed recognition of the problem and the delayed actions in 
cleaning it up surely added to the eventual costs, which totaled about $\$ 160$ billion. $^{27}$

\section{B. The commercial bank experience. ${ }^{28}$}

Commercial banks too entered the 1980s after 45 years of relative calm and prosperity. Not having been as narrowly restricted in activities as S\&Ls and especially not having been forced exclusively to borrow short and lend long, banks were not seriously affected by the high interest rate environment of the late 1970s and early 1980s and thus were not in the same financial straits as were S\&Ls.

Nevertheless, economic regulation -- especially branching limitations -- played a large role in the structure of the industry and its vulnerability over the next decade. As of the beginning of 1980 there were more than 14,000 banks in the U.S.; over half of them were small -- under $\$ 25$ million (!) in assets. Interstate branching was prohibited, and a number of states prohibited any branching (unit banking states, such as Texas or Illinois) or greatly limited branching even within their own state boundaries. Effectively, there were large numbers of banks, many of them small, all of them confined to locations within states and many confined to substantially smaller communities. Such limitations made them more vulnerable to local or regional fluctuations.

The strong encouragement for commercial real estate investment provided by the high and rising price of petroleum in 1980 and by the Economic Recovery Tax Act of 1981 presented the same temptations for loans by commercial banks as was true for their S\&L brethren, especially since 1982 legislation eased restrictions on banks' abilities to make commercial real estate loans.

\footnotetext{
${ }^{27}$ See FDIC (1997, ch. 4).

${ }^{28}$ See FDIC (1997).
} 
Many banks did expand into commercial real estate loans and then were hurt when the price of petroleum declined, the Congress reversed course in the 1986 Tax Act, and commercial real estate prices declined substantially, especially in the Southwest and then in the Northeast. Further compounding some banks' woes, especially smaller rural banks in the Midwest, was the decline in the prosperity of U.S. agriculture in the mid 1980s. And regional recessions, the national recession of 1990-1991, and the recession in California in the early 1990s exacerbated some banks' problems. $^{29}$

Also, as was true in the case of S\&Ls, bank regulators were understaffed in the early 1980s and had been lulled by the calmness of the previous decades. They were too slow to react when troubles did arise. Also, there had been a tendency to replace some on-site examinations with offsite monitoring, which meant that direct scrutiny of managers and managerial practices (and the quality of the data that were used for off-site monitoring) occurred less frequently.

Over the period 1980-1994 more banks -- over 1,500 -- than S\&Ls failed. But on average the failed banks were considerably smaller than their S\&L counterparts, and the average seriousness of their insolvencies was considerably less as well. The eventual loss to the FDIC was less than $\$ 40$ billion -- less than a quarter of the size of the S\&L debacle. The FDIC insurance funds were large enough to be able to absorb the losses, so that the FDIC did not fail they way that the FSLIC failed, although in 1991 the expected losses of the FDIC looked sizable enough that there was considerable worry that the fund might become insolvent and require taxpayer assistance. The rapidly improved fortunes of the banking sector, as well as the U.S. economy more generally,

${ }^{29}$ Large money center banks experienced problems in the mid 1980 s because of failed loans to less developed countries (LDCs). But partial repayments and the stretching out of the losses allowed the banks eventually to absorb the losses without failing themselves. 
rapidly dispelled the fears.

\section{The lessons}

Over the past two decades the U.S. has gone through two major waves of insolvencies: by S\&Ls and by banks. The timing and some of the causes of the two waves were similar. When this experience is seen through the filter of the discussion in the previous Sections, there are important lessons that can be learned.

1. Economic regulation that limited S\&Ls' and banks' operating flexibility tended to make them more vulnerable to changes in their environments and thus more prone to insolvencies. Efforts to cosset and protect have, paradoxically, made these depository institutions less safe.

2. Safety-and-soundness regulation has a valuable role to play in limiting moral hazard behavior and thus preserving the stability of banks. The details of the regulation and its implementation are important in determining its efficacy. Deposit insurance plays a useful supplementary role in reassuring depositors against regulatory failures. ${ }^{30}$

3. Minimum capital requirements that are sensitive to the risks undertaken by a bank and that are forward looking are essential as a buffer and as a deterrent to excessive risk-taking. As banks slip below the minimum levels, they should be subject to heightened levels of scrutiny and tighter restrictions on actions. When they reach insolvency, the owners (whose net worth is now zero) should be removed, as should senior managers who were responsible for the deteriorated financial position of the bank. Prompt action is essential for maintaining a system of incentives and disincentives as well as for limiting any regulatory evasions that might occur by desperate

\footnotetext{
30 Deposit insurance may lull depositor scrutiny of banks. But most depositors are not information specialists and are unlikely to be able effectively to monitor their banks.
} 
owners/managers. Either new owners for the bank should be found (with the government deposit insurance fund "filling the hole" of the insolvency), or the bank should be liquidated and the depositors paid off. A temporary "holding pen" for an insolvent bank under government auspices may be unavoidable, while the best course of action is considered. But rapid disposal is usually the cost-minimizing strategy, since the managers of a "holding pen" bank rarely have the proper incentives to maximize value. ${ }^{31}$ Rapid action -- in spotting problems, imposing restrictions, and disposing of an insolvent back -- are generally the means of minimizing the costs of insolvencies.

4. An accounting framework that reflects current values of assets and liabilities is essential for the proper calculation of capital and for taking prompt corrective action as a bank slips below its minimum level. The existing accounting framework (GAAP) is not adequate for these purposes, because it is fundamentally backward looking, emphasizing historical values rather than focusing on current values. During the episodes of the 1980s, S\&L regulators and bank regulators were often inhibited from imposing restrictive measures sooner on individual institutions because the backward-looking GAAP framework was not registering the current deteriorated conditions that the regulators were recognizing. For bank regulatory purposes, GAAP must be replaced by a current (market) value framework.

5. Regulatory determination of the competency of bank managers and practices are an important part of safety-and-soundness regulation. On-site visits are integral to that process.

6. Activities limitations have a proper role, but in a structured way. The key determination is whether an activity is "examinable and supervisable" -- i.e., whether examiners and supervisors can assess an activity, know when it is competently managed, and determine appropriate capital

${ }^{31}$ This is also true for the assets that the government acquires through the liquidation of failed banks. See FDIC (1998). 
requirements. If they can, then there should be few problems in permitting the activity within the bank. If they cannot, then the activity should be forbidden to the bank but should be permitted either as a separately capitalized subsidiary of the bank ${ }^{32}$ or of the bank's holding company -preferably the former. $^{33}$

7. Safety-and-soundness regulation must be enforced by a cadre of adequately staffed, paid, and trained examiners and supervisors.

\footnotetext{
${ }^{32}$ I.e., the bank should not be able to count as an asset the net worth of the subsidiary.

${ }^{33}$ See White (1996) and Shull and White (1998).
} 


\section{$\underline{\text { VI. Conclusion }}$}

Finance is not easy; neither is financial regulation, especially safety-and-soundness regulation. But there are substantial gains to doing it well; and equally serious losses can occur from doing it poorly. Since 1990 a number of countries -- including Japan, France, Sweden, Spain, Mexico, Thailand, Korea, Venezuela, Indonesia -- have experienced serious and costly insolvencies among their banks.

Starting a decade earlier, during the 1980s and early 1990s, the U.S. went through two waves of insolvencies: by savings and loan institutions (S\&Ls) and by banks. The former wave was especially costly and painful, though the latter wave too generated costs in the tens of billions of dollars and resulted in the failure of over 1,500 banks. The lessons of these experiences have been available. Absorbing these lessons might have reduced the costs of the experiences of these other countries. It is a pity that political learning is often so slow. 


\section{$\underline{\text { References }}$}

Berger, Allen N. and Gregory F. Udell, "Securitization, Risk, and the Liquidity Problem," in Michael Klausner and Lawrence J. White, eds., Structural Change in Banking. Homewood, Ill.: Business One Irwin, 1993, pp. 227-291.

Diamond, Douglas W. and Philip H. Dybvig, "Bank Runs, Deposit Insurance, and Liquidity," Journal of Political Economy, 91 (June 1983), pp. 401-419.

Edwards, Franklin R., The New Finance: Regulation and Financial Stability. Washington, D.C.: American Enterprise Institute, 1996.

Federal Deposit Insurance Corporation, History of the Eighties: Lessons for the Future. Washington, D.C.: 1997.

Federal Deposit Insurance Corporation, Managing the Crisis: The FDIC and RTC Experience, 1980-1994. Washington, D.C.: 1998.

Gorton, Gary and Andrew Winton, "Banking in Transition Economies: Does Efficiency Require Instability?" Journal of Money, Credit and Banking, 30 (August 1998), pp. 621-650.

Kroszner, Randall S., "The Evolution of Universal Banking and Its regulation in Twentieth Century America," in Anthony Saunders and Ingo Walter, eds., Universal Banking: Financial System Design Reconsidered. Chicago: Irwin, 1996, pp. 70-99.

La Porta, Rafael, Florencio Lopez-de-Silanes, Andre Schleifer, and Robert W. Vishny, "Legal Determinants of External Finance," Journal of Finance, 52 (July 1997), pp. 1131-50.

Laporta, Rafael, Florencio Lopez-de-Silanes, Andre Schleifer, and Robert W. Vishny, "Law and Finance," Journal of Political Economy, 106 (December 1998), pp. 1133-1155.

Levine, Ross, "The Legal Environment, Banks, and Long-Run Economic Growth, Journal of Money, Credit and Banking, (August 1998), pp. 596-613

Levine, Ross, "Law, Finance, and Economic Growth," Journal of Financial Intermediation, 8 (January/April 1999), pp. 8-35.

Levine, Ross and Sara Zervos, "Stock Markets, Banks, and Economic Growth," American Economic Review, 88 (June 1998), pp. 537-558.

Litan, Robert E., What Should Banks Do? Washington, D.C.: Brookings Institution, 1987.

Nakamura, Leonard I., "Commercial Bank Information: Implications for the Structure of Banking," in Michael Klausner and Lawrence J. White, etc., Structural Change in Banking. Homewood, Ill.: Business One Irwin, 1993, pp. 131-160. 
Postlewaite, Andrew and Xavier Vives, "Bank Runs as an Equilibrium Phenomenon," Journal of Political Economy, 95 (June 1987), pp. 485-491.

Shull, Bernard and Lawrence J. White, "The Right Corporate Structure for Expanded Bank Activities," Banking Law Journal, 115 (May 1998), pp. 446-476.

Stiglitz, Joseph and Andrew Weiss, "Credit Rationing in Markets with Imperfect Information," American Economic Review, 71 (June 1981), pp. 393-410.

Strahan, Philip, "Borrower Risk and the Price and Nonprice Terms of Bank Loans," Federal Reserve Bank of New York (July 1999), mimeo.

White, Lawrence J., The S\&L Debacle: Public Policy Lessons for Bank and Thrift Regulation. New York: Oxford University Press, 1991.

White, Lawrence J., "The Community Reinvestment Act: Good Intentions Headed in the Wrong Direction," Fordham Urban Law Journal, 20 (Winter 1993), pp. 281-292.

White, Lawrence J., "U.S. Banking Regulation," in Benn Steil, ed., International Financial Market Regulation. London: Wiley, 1994, pp. 15-35.

White, Lawrence J., "The Proper Structure of Universal Banking: "Examinability and Supervisability," in Anthony Saunders and Ingo Walter, eds., Universal Banking: Financial System Design Reconsidered. Chicago: Irwin, 1996, pp. 682-695. 
Table 1: Salient Features of U.S. Commercial Banks (as of June 30, 1999)

$\begin{array}{rc}\begin{array}{c}\text { Total } \\ \text { Industry }\end{array} & \begin{array}{c}\text { Banks }>\$ 10 B \\ \text { in Assets }\end{array} \\ 8,675 & 77 \\ \$ 5,468 & \$ 3,612 \\ \$ 936 & \$ 710 \\ \$ 3,681 & \$ 2,271 \\ 8.53 \% & 7.94 \%\end{array}$

Source: FDIC 
Table 2: Bank Failures and Deposit Insurance Losses ${ }^{*}$ 1940-1988

$\begin{array}{cc}\text { Number of } & \text { Deposit Insurance } \\ \text { Bank Failures } & \text { Losses }(\$ M)\end{array}$

Decade totals:

$\begin{array}{rrr}1940-1949 & 99 & \$ 6 \\ 1950-1959 & 28 & 3 \\ 1960-1969 & 43 & 8 \\ 1970-1979 & 76 & 117 \\ 1980-1989 & 1,086 & 22,961 \\ 1990-1999^{+} & 509 & 13,769\end{array}$

Individual years:

1980

1981

1982

1983

1984

1985

1986

1987

1988

1989

1990

1991

1992

1993

1994

1995

1996

1997

1998

$1999^{+}$

$\begin{array}{rr}11 & \$ 31 \\ 10 & 782 \\ 42 & 1,169 \\ 48 & 1,407 \\ 80 & 1,640 \\ 120 & 1,007 \\ 145 & 1,776 \\ 203 & 2,024 \\ 280 & 6,924 \\ 207 & 6,201 \\ 169 & 2,773 \\ 127 & 6,189 \\ 122 & 3,666 \\ 41 & 645 \\ 13 & 182 \\ 6 & 87 \\ 5 & 40 \\ 1 & 4 \\ 3 & 179 \\ 2 & \mathrm{n} . \mathrm{a} .\end{array}$

Source: FDIC

* Includes mutual savings banks.

+ Through June 1999. 
FIGURE 1: STYLIZED BALANCE SHEET OF A HEALTHY BANK

\begin{tabular}{c|l} 
Assets & Liabilities \\
\hline \$100 (loans) & $\$ 92$ (deposits) \\
\hdashline$\quad \$ 8$ (net worth, owners' \\
equity, capital)
\end{tabular}




\section{FIGURE 2: THE SPECTRUM OF INFORMATIONAL OPAQUENESS/TRANSPARENCY}

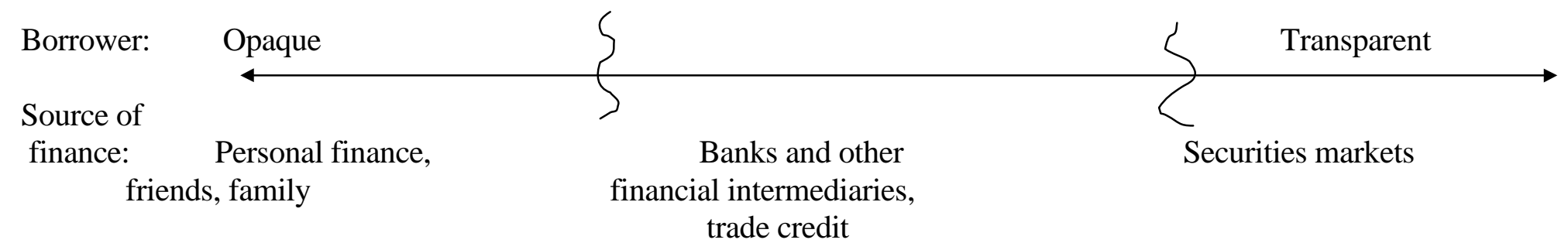


FIGURE 3: TWO DETERMINANTS OF OPAQUENESS/TRANSPARENCY

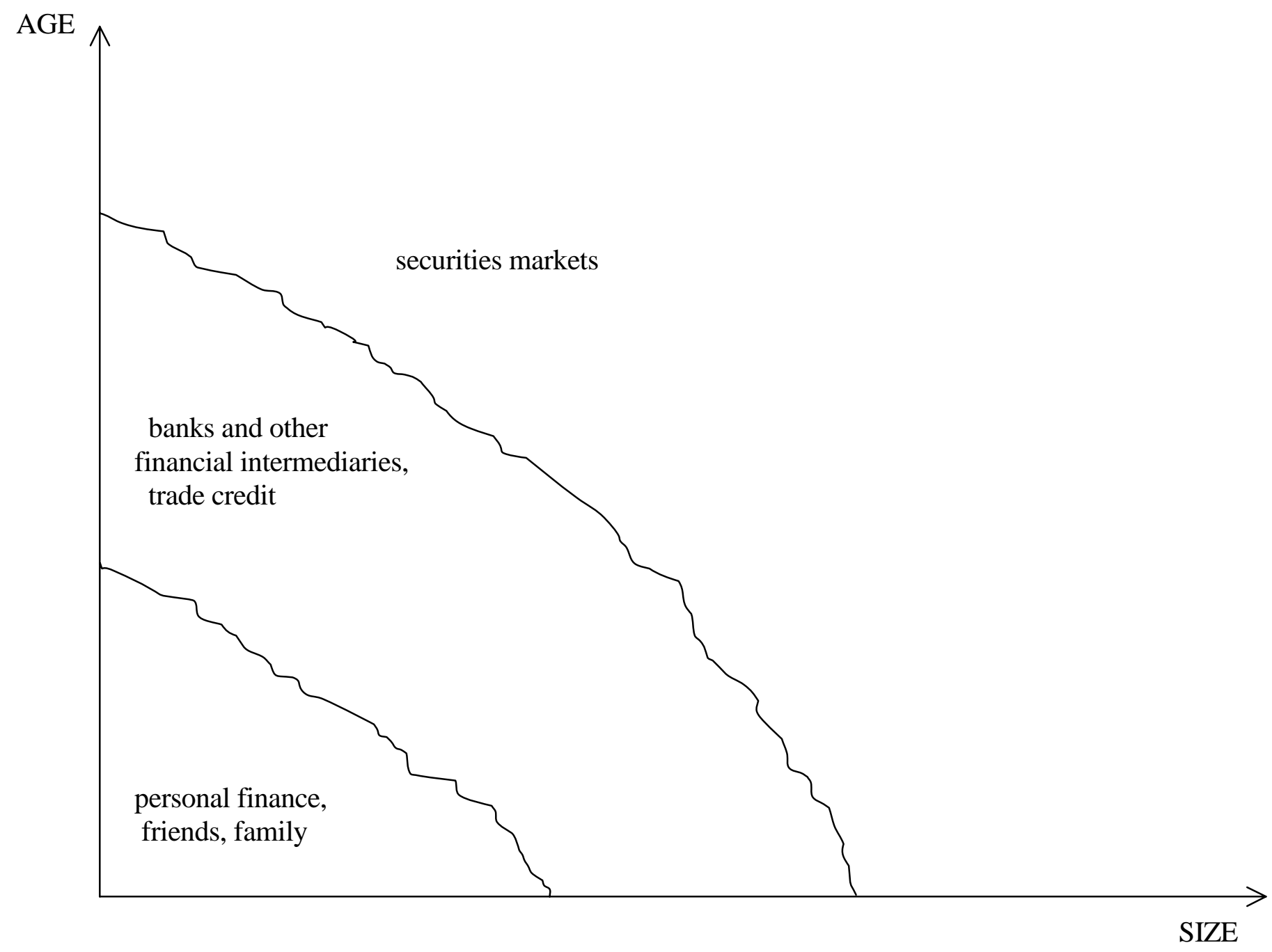


FIGURE 4A: STYLIZED BALANCE SHEET OF A HEALTHY BANK

\begin{tabular}{r|l} 
Assets & Liabilities \\
\hline \$100 (loans) & $\$ 92$ (deposits) \\
\hline-98 (net worth, owners' \\
equity, capital)
\end{tabular}

\section{FIGURE 4B: STYLIZED BALANCE SHEET OF} A DEEPLY INSOLVENT BANK

\begin{tabular}{c|l} 
Assets & Liabilities \\
\hline \$80 (loans) & $\$ 92$ (deposits) \\
& $\begin{array}{r}\$ 12 \text { (net worth, owners } \\
\text { equity, capital) }\end{array}$
\end{tabular}

